\title{
TAX INCENTIVES: PROBLEMS IN IDENTIFICATION AND ACCOUNTABILITY
}

\author{
ALEX MACNEVIN*
}

\begin{abstract}
In this commentary on Thumbs, Fingers, and Pushing on String: Legal Accountability in the Use of Financial Incentives by Webb, the author tackles the thorny issue of defining tax expenditure incentives. He argues that although tax expenditure incentives are a powerful financial instrument for the federal government, scarce information is available about their effectiveness, and thus there are genuine problems with respect to accountability.
\end{abstract}

\section{TABLE OF CONTENTS}

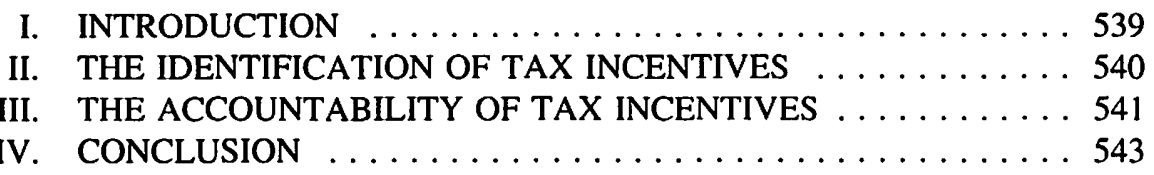

\section{INTRODUCTION}

Mr. Webb's central thesis is that government's fingers (essentially financial incentives), like its thumbs (essentially regulatory and coercive instruments), need significant (i.e. similar) structuring to ensure accountability. He sets out the following four general areas where he feels additional accountability is typically required for incentives: with respect to federal/provincial jurisdiction; with respect to legislative structure; with respect to advance notice and comment procedures; and with respect to notions of natural justice and procedural fairness.

Not surprisingly, Mr. Webb's perspective is primarily legal in focus; he is concerned with what he views as deficiencies in legal structure and channels of legal authority and recourse. As an economist, I am not qualified to discuss the legal issues raised by $\mathrm{Mr}$. Webb. However, his passing reference, in a related paper to be delivered at this conference, refers to the Auditor General's estimates that there are $\$ 41$ billion and $\$ 28$ billion in, respectively, direct expenditure incentives and tax expenditure incentives.' Incentives are thus ultimately about money that is, who gets it, why, how, how much, what is the effect and how is this accounted for and therefore have important economic as well as legal dimensions. While Mr. Webb's paper deals with both expenditure and tax incentives, my comments concentrate on the latter, with which I am most familiar.

Tax Evaluation Division, Federal Department of Finance, at time of writing.

Report of the Auditor General of Canada 1986 (Ottawa: Supply and Services, 1986) 4.17. I would note, however, that an important caveat in the tax expenditure document indicates that estimates for individual tax measures cannot be added together to produce a meaningful total value. This is primarily due to the fact that the estimating technique used in valuing measures does not reflect interactions between measures. 


\section{THE IDENTIFICATION OF TAX INCENTIVES}

One fundamental problem with respect to accountability in the area of taxation arises because of difficulties in defining what is or is not a tax expenditure or a tax incentive. A central aspect of accountability relates to the seemingly simple basic requirement for documenting the amounts of money foregone through various incentives. Mr. Webb notes that information on the costs of tax incentives are reported only sporadically in tax expenditure accounts, the last of which was put out by the Minister of Finance in 1985. $\mathrm{He}$ also points out that tax incentives are removed from the normal budgeting and estimating procedures that apply to many other incentives on the expenditure side (which, incidentally, he views as generally deficient).

The infrequent release of tax expenditures (or, as they were called in the 1985 document, selective tax measures) tables may in part reflect the absence of a legal requirement that they be produced on a regular basis. ${ }^{2}$ They also, however, reflect significant conceptual difficulties encountered in constructing such accounts as well as prevailing concerns about the extent of their usefulness, including their interpretation. Difficulties in this regard were highlighted in a 1988 conference on tax expenditures and accountability in taxation that was jointly sponsored by the Department of Finance and the John Deutsch Institute of Queen's University. ${ }^{3}$

In the opinion of many of the public finance experts who participated in the conference, tax expenditures often cannot easily be distinguished from structural parameters of the tax system. Identification of tax incentives necessitates comparison of the actual tax system with an ideal "benchmark" tax system. This is entirely different from the case of direct expenditures where no comparable reference base is required. One practical difficulty confronting tax expenditure accounting is that any view about what the tax base should be is essentially a value judgement and hence will vary from individual to individual. The result is that items which may be viewed as tax expenditures under one particular benchmark tax system may not be viewed as such under another benchmark. For example, tax deductions for retirement savings plans are a tax expenditure under an annual income tax benchmark, but are not tax expenditures under lifetime income tax or consumption tax benchmarks. Since the federal tax system contains a mixture of elements of all three of these tax regimes, considerable difficulties in identifying tax expenditures exist.

Related additional complexities arise because an actual tax system can only approximate the desirable characteristics of any particular normative view as to what should be taxed. For example, while economists may be able to define fairly precisely what real economic income is over a particular period of time under an income tax base, it is impractical to design an income tax system that has the actual characteristics dictated by theory. The result of is that in some instances, it is not clear how a particular tax

2. There is, for example, a legal requirement for the annual production of tax expenditure tables in the United States.

3. See N. Bruce, ed., Tax Expenditures and Government Policy: Proceedings of the Seventh John Deutsch Roundtable on Economic Policy (Kingston: Queen`s University, 1988). 
measure or group of related tax measures should be viewed under an actual tax system that is inevitably only an imperfect approximation of a chosen "benchmark" tax system.

Many examples can be given to illustrate the difficulties that arise in this respect. For example, considerable uncertainty arises about how the various provisions relating to the taxation of capital gains should be treated for tax expenditure accounting purposes under an income tax regime that taxes nominal gains on a realization basis rather than real gains on an accrual basis. The integration of the personal and corporate income tax systems gives rise to other examples. Under a view that treats the integrated personal and corporated tax systems as the benchmark, the dividend tax credit is not a tax expenditure. Under one that treats the personal and corporate tax systems as separate benchmark systems, it is.

The tax expenditure treatment of cash accounting for farmers and fishermen provides another example. Economists are uncomfortable on tax principle grounds with the deductibility of expenditures on inventory because such expenditures merely reflect the transfer of one asset (cash) into another asset (inventory). Accrual accounting rules, which are required of other types of businesses, effectively result in unsold inventories being added back into income at the end of the year so that no deduction in the year is permitted. Past tax expenditure accounts have identified cash accounting as a tax expenditure, although it is far from obvious that, at least for full-time farmers and fishermen, cash accounting on balance results in lower tax liabilities over time or that from their perspective it is anything more than a peculiar tax wrinkle. It is notable that there is no dollar estimate of the value of cash accounting in previous tax expenditure accounts.

\section{THE ACCOUNTABILITY OF TAX INCENTIVES}

One common theme that emerged from the conference on tax expenditures and accountability was that, in light of the many difficulties in identifying tax expenditures, it might be desirable to present tax expenditure information from the perspective of a number of different normative benchmark systems. This would highlight aspects of the tax system from these different perspectives. It would, however, achieve this at the cost of considerable added complexity in interpreting the accounts, particularly to users of the accounts who were not tax experts. There may, therefore, be somewhat of a conflict between the usefulness of tax expenditure accounts in their role as an instrument of tax analysis versus their role as an accountability instrument where clarity and simplicity of presentation and interpretation have high priority. It may be possible to strike a compromise by, for example, ensuring that tax expenditure accounts clearly identify the key tax measures that most reasonably could be substituted for direct expenditure programs. This would facilitate comparisons of tax expenditures data with those for comparable programs on the direct expenditure side in the Public Accounts and thereby permit a more complete assessment of the incentives and subsidies applying to particular

4. Problems in identifying tax expenditures are highlighted by the fact that in the United States, the tax expenditure accounts prepared by Congress are considerably different from those produced by the Executive Office. 
sectors, geographical regions, and so on. Such an approach would foster the accountability objective of "functional equivalence" identified by Mr. Webb.

Problems with compiling tax expenditures accounts are highlighted when the very structure of the tax system undergoes major changes, such as with the income tax reform of 1988 and with the introduction of the GST to replace the manufacturers sales tax. In such circumstances, presentation of tax expenditure information must be thoroughly reformulated to reflect the revised tax regimes and, indeed, the changing benchmark norms. This can give rise to problems of lack of continuity and comparability of data over time. As an additional practical matter, significant lags in the availability of taxation data may delay the release of tax expenditure tables that reflect the new regimes. There are two and three year lags for, respectively, personal income tax data and corporate income tax data.

Delays in the availability of taxation data are particularly problematic since it is typically much more difficult to forecast the ultimate cost of tax incentives than is the case for direct expenditure incentives. The main reason for this is that tax incentives are almost always open-ended while direct expenditure incentives are typically subject to an overall budget constraint. The total cost of a tax incentive thus depends entirely on the usually difficult to predict take-up response of taxpayers, which can give rise to considerable uncertainty in budgeting. ${ }^{5}$

There are thus significant difficulties with tax expenditure analysis even as an accounting device for providing estimates of the cost of individual tax measures. Judged by the other criteria identified above they are substantially more deficient since they provide no insight whatsoever into the questions of who benefits from tax incentives, why, and what are their effects. Analytical techniques, (such as full evaluations) in addition to accounting techniques, are required in order to provide a complete picture of both the cost and the efficacy of tax measures. I would note, however, that the problems in identifying tax expenditures, particularly in an environment of changing tax structures or norms, make it difficult to systematically evaluate tax expenditures or incentives on a routine cyclical basis as is done for direct expenditure programs.

The limitations of tax expenditures information naturally raise questions about the appropriate amount of scarce analytical resources that should be devoted to the preparation of tax expenditure tables, rather than to alternative or complementary tools of accountability such as in-depth studies of the rationale and cost-effectiveness of particular tax measures and related groupings of tax measures; irrespective of whether there is a consensus as to their tax expenditure status under any particular benchmark tax system. The Department of Finance has long wrestled with the practical difficulties and trade-offs

5. The exercise of administrative discretion is not, at least in my view, a generally acceptable solution to this for tax incentives. While administrative discretion in the allocation of funds may be acceptable in the case of direct expenditure programs where there is budgetary accountability for funds dispersed, there is no similar check on departments or agencies administering the allocation of tax dollars. Moreover, the department or agency assigned the discretionary authority for a tax measure might not have sufficient expertise in the area of tax law to ensure compliance in that respect. 
involved in compiling tax expenditure data and other accountability information that is, on balance, most revealing with respect to the underlying structure of the tax system. The proceedings of the John Deutsch Conference indicate clearly that there are no easy solutions to the problems.

\section{CONCLUSION}

As noted earlier, Mr. Webb also makes reference to the adequacy of current budgeting procedures for tax incentives. The problem of identifying and measuring tax incentives separately from the "normal" parameters of the tax system hints at the intimate relationship between tax expenditures or (tax incentives) policy and the more limited process of modifying and improving the tax system that is the strict design of tax policy. This latter process is a natural component of the government's routine budget procedures and is subject to well-known budget conventions. Procedures relating to the introduction or modification of tax incentives must therefore inevitably be conducted within that somewhat restrictive environment. Can improvements be made which reflect both the need for improved budgeting procedures for tax incentives and the unique environment in which tax measures are designed and modified? I am sure they can but I am considerably less sure that such procedures can be routinized through legislative structure or guidelines.

In summary, I fully support the general thrust of Mr. Webb's paper of the need for improved structures and instruments of accountability. In my view, however, the pursuit of that objective must be tempered by recognition of the significant practical obstacles that arise because of the unique characteristics of tax incentives. 